\title{
Analysis on the Present Situation and Problems of Zhengzhou Airport Zone under the Background of "the Belt and Road" Initiative
}

\author{
Xu Wenjun \\ Administrative Engineering College, Zhengzhou University, No.100 Science Avenue, High - tech Zone, \\ Zhengzhou City, Henan Province, China
}

Keywords: "Belt and Road" initiative, Zhengzhou Airport Zone, Opportunities and problems.

\begin{abstract}
B\&R" (the Belt and Road) initiative make China's economic development reach a new high, however, there is a matter about how to seize the new opportunities in this trend to achieve rapid development of the provinces. It is worth studying how Zhengzhou Airport Economic Zone, one of national key projects of the "B\&R" initiative, to seize the opportunity to make use of regional advantages to achieve take-off of economic. This paper mainly analyzes the current situation, opportunities and problems faced by Zhengzhou Airport Zone in the "B\&R" initiative construction, and puts forward suggestions for how to deal with the opportunities and challenges faced by Zhengzhou.
\end{abstract}

\section{INTRODUCTION}

"B\&R", referring to the Silk Road economic belt and the Silk Road on the sea, is an idea/initiative of development to cooperate with the countries along the belt and achieve the win-win situation (Guoyou Song, 2015). It is a major national strategy to co-ordinate the international and domestic. Zhengzhou is an important transportation hub in the whole country. It is also an important node to connect the Silk Road economic belt with the 21st century maritime Silk Road. It has many advantages and conditions in building a strategic hub for opening up to the outside world, building an open economic highland and an important gateway (Xiaoyan Zhu, 2017). Zhengzhou Airport Zone actively integrate and serve the "B\&R" initiative, which can bring more opportunities to the development of Henan economy and achieve sustainable economic development.

At present, many scholars have studied the development of Zhengzhou Airport Zone. By analyzing characteristics of aviation logistics of several international airport, Zhou Yang has studied the development of Zhengzhou airport and the existing problems, then put forward the corresponding countermeasures (Yang Zhou, 2014). Jiu Jingli analyzed the problems of infrastructure, industrial environment, oriented industry and talent, then put forward solutions (Jingli Jiu, 2014). Wang Jiayuan studied the development opportunities that "B\&R" strategy has brought to Henan (Jiayuan Wang, 2015). Although the research of the pre-scholars has great guiding significance, but they only focused on the problems and countermeasures, the study of the development of the airport under the influence of "B\&R" initiative is a little lack. This paper studies the development of Zhengzhou Airport Zone in the background of "B\&R" initiative, with best wishes to provide the development of airports some help.

\section{THE PRESENT SITUATION OF ZHENGZHOU AIRPORT ZONE}

In March 2013, the approval of the Zhengzhou Airport Comprehensive Economic Zone Experimental Development (2013-2025) was a big event for Zhengzhou Airport Zone, making it be the forerunner of national airport economic development. Its main objective is to build Zhengzhou into an international cargo airport, and further develop into a joint hub of the world's major airports and major economies, then form a comprehensive land and air convergence of modern integrated transport system, and gradually develop into an important international aviation logistics center, using the logistics industry to promote industrial development, and using the hub effect to attract all kinds of industries, vigorously develop the hub economy. In addition, the other goal is make efforts to build a modern industrial economic base, making it an important gateway that opens to the outside world and an important driving force to promote the development of the Central Plains Economic Zone.

Over the past four years, the overall development of the Zhengzhou Airport hub economy is in good shape, and the Airport Zone has achieved remarkable achievements in all aspects. Infrastructure construction has been improved, integrated transport hub has been initially formed, all of these lay a solid foundation for establishing a status of large hub and the development of hub economy. As of 2017, Zhengzhou Airport has opened to the Luxembourg, New York, Frankfurt, Singapore, Jakarta, Vancouver and other countries and regions 43 passenger and freight routes, and has built the world's major hub airports and major economies of the air Silk Road, passenger and freight growth rate ranked in the forefront of the country for many years. Airport Zone has six designated port of import, including chilled aquatic products, fruit etc., having the largest number of inland functional ports. There are 43 freight forwarding companies and logistics enterprises settled in Airport Zone, including Foxconn, DHL, Sinotrans, sea Bunda 
etc., making industries cluster together come true. Aviation logistics park has also introduced more than 30 logistics projects, including the Vipshop, Suning etc. Industries relying on aviation logistics is accelerating the development, being a strong support for the construction of aviation logistics and freight hub.

Main economic indicators maintain high growth, and aviation logistics develop rapidly. Table 1 and figure 1 show that the GDP of Airport Zone has grown steadily in recent years. In 2016, GDP has reached 62.25 billion yuan, more than two times in 2013; Zhengzhou Airport passenger throughput in 2016 exceeded 20 million people, more than two times in 2013, cargo and mail throughput increased nearly twice. In the first half of 2017, the gross domestic product (GDP) reached 29.238 billion yuan, up 11.6 percent year on year, exceeding the annual gross domestic product of 2013; passenger throughput is 11.34 million, above-scale industrial added value is 11.64 billion yuan.

Table 1: Passenger and Freight Transport in Xinzheng International Airport.

\begin{tabular}{|c|c|c|c|c|}
\hline Year & $\begin{array}{c}\text { Passenger } \\
\text { throughput } \\
\text { (million) }\end{array}$ & $\begin{array}{c}\text { passenger } \\
\text { throughput } \\
\text { growth (\%) }\end{array}$ & $\begin{array}{c}\text { total cargo } \\
\text { (Million tons) }\end{array}$ & $\begin{array}{c}\text { total cargo } \\
\text { growth (\%) }\end{array}$ \\
\hline 2013 & 1314 & 12.6 & 25.6 & 69.5 \\
\hline 2014 & 1580.5 & 20.3 & 37 & 44.5 \\
\hline 2015 & 1729.7 & 9.4 & 40.3 & 8.9 \\
\hline 2016 & 2076.3 & 20 & 45.7 & 13.4 \\
\hline
\end{tabular}

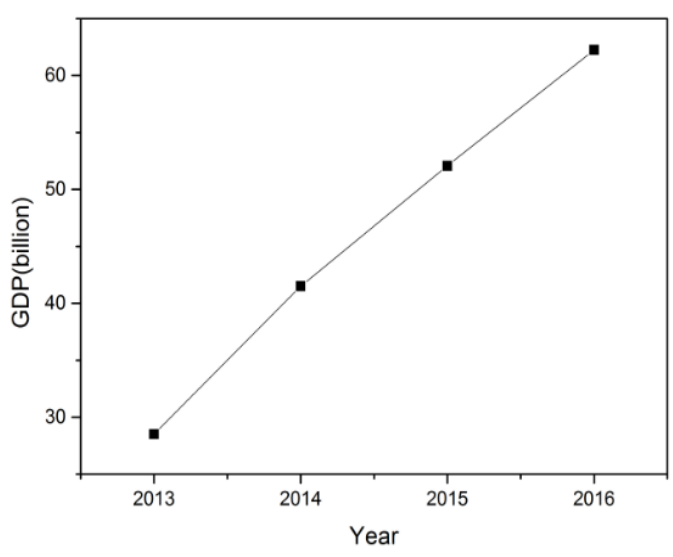

Figure 1: 2013-2016 GDP of Airport Zone.

\section{THE OPPORTUNITIES BROUGHT BY "B\&R" INITIATIVE FOR ZHENGZHOU AIRPORT ZONE}

First, location advantages can further enhance. Zhengzhou is located in the Central Plains and has convenient transportation. For example, there are Beijing-Guangzhou line connecting north with south and Longhai line connecting east with west (Xinhong Pei, 2016). In addition, it's also an Interchange of LianHuo high-speed, 107 National Road. There are expressway and subway to airport in the city. The Airport Zone is not only integrated with Zhengzhou City, but also integrated with the outside world conveniently. This is the reason why Zhengzhou has become an important logistics hub city and played a very important role in the layout of national economic and the pattern of logistics development. In the "B\&R" initiative, Henan is in the intersection of the Silk Road on sea and the Silk Road on land, so the strategic position is obvious. There are China Railway Express which is mainly used for trading with countries and regions along the line. The aim is to achieve connection between the central and western regions of China and Europe and make Henan Province become the main distribution center and transit station of China's cargo transport. Zhengzhou is the core city and key hub of "B\&R" initiative. The Airport Zone located in Zhengzhou can not only make use of the natural geographical advantages of Henan province, but also make use of national strategy. This can bring some opportunities to Zhengzhou Airport Zone in participating in the "B\&R" initiative and creating "Silk Road in the air" and promoting the trade between Henan and the EU (Xinshun Tong, Xiaokang Qin, 2014).

Second, it can promote the development of aviation logistics globalization. "B\&R" constructed a pattern which is connected with the world. This is in line with the development of aviation logistics. The unique geographical location and the perfect transport network of Henan Province can vigorously promote the development of the logistics industry. Zhengzhou Airport Zone, making use of the natural traffic advantages and multimodal transport and aviation logistics system, can create a nationwide, world-oriented trade concentration and promote the transportation of international goods. "B\&R" is a strategic guidance for Zhengzhou airport to develop towards the international aviation logistics center and the international integrated logistics area. It will increase the trade between Henan and the world, promote economic development and make Airport Zone being logistics channel hub that connected to all directions.

Third, it can promote infrastructure construction. "B\&R" initiative make Zhengzhou Airport Zone become an important hub that encourages Henan to connect with the world, this bring a huge impetus to the local government and enterprises. In order to actively integrate into the "B\&R", the relevant government departments vigorously build infrastructure and nurture the development of new advantages through scientific planning. Such as the construction of the Menghua railway coal transportation channel and Chinese intelligent backbone network. The first phase of the Chinese intelligent backbone network has been put into use, the second phase of the project has been basically completed pile foundation and foundation construction. After completion, the project will become a new electric business center. It is Significant for Henan to become the important hub of "B\&R" which is connected with world and promote development of economy and society. Various construction projects are in full swing in progress. The purpose is to lay a solid foundation for making Zhengzhou become a modern, international integrated transport hub and logistics center. 


\section{THE MAIN DEVELOPMENT PROBLEMS OF ZHENGZHOU AIRPORT ZONE}

First, industry support is not strong. In Zhengzhou Airport Zone, there are three leading industries which is aviation logistics, high-end manufacturing industry and modern service industry. But at present, among of all, only the development of intelligent terminal industry is better. In the tertiary industry, financial industry, logistics and electronic information industry is still in the early stages of growth. Food processing and other traditional industries still occupy a certain proportion. Industry has not yet formed a complete industrial chain, and it is hard to adapt to the aviation metropolis competition requirements. To develop the industry as soon as possible, only intelligent terminal is not enough to support the overall development. It's necessary to further enhance high-end equipment manufacturing, modern logistics on the basis of other the existing excellent industry, only in this way can we expand the scale and upgrade the level.

Second, at the background of the new normal, our nation requires the Airport Zone not only to ensure its development trend, but also to achieve sustained and rapid growth. At the same time, Zhengzhou Airport Zone must take measures to improve the quality and efficiency, and enhance the capacity of supply effectively. However, under the current environment, the investment and factor driving force of enterprise development is weakened, the environmental constraints and the competition are intensified, and the risk is increased. In addition, economic globalization has encountered twists and turns, international trade and investment downturn. All of these bring serious challenges to the development of Zhengzhou Airport Zone.

Third, lack of innovation and innovative talent. At present, the community promote innovation to lead the development. A new round of scientific and technological revolution is ready. The industry which lets smart manufacturing as the core is accelerating its transform. The new economy based on the Internet is developing rapidly. These new trends require Zhengzhou Airport Zone to strengthen its innovation-driven strategy. But at present, one of the shortcomings of the airport area is the lack of innovation ability and high-level talent, especially professionals sever the airport economy.

\section{COUNTERMEASURES}

The goal of Zhengzhou Airport Zone is to integrate into the "B\&R" construction, vigorously promote the construction of Henan Free Trade Experimental Zone, and build a modern three-dimensional transport system and logistics channel hub which can connect the inside with outside of China, basically form an inland open upland. As an important support of "B\&R" construction and economic development of Henan, how to seize the opportunity and lead the development of the airport is an important issue that should be considered at present. Here are some suggestions:

First, because the economic development runs into the new normal, people should formulate a scientific and rational overall development plan and guide industry to restructure comprehensively, making cluster of industrial to accelerate the transformation of industry. Cluster of industrial can produce economies of scale and save space transaction costs. In addition, because the distance among enterprises are close, fierce competition will force enterprises to continue to carry out technological innovation and organizational management innovation. In this way, a competitive industrial groups can be formed, thus driving the province's industrial transformation and development.

Second, people should promote institutional innovation, industrial innovation and platform construction continuously, in order to explore a copyable experience for the province's reform and innovation. This can a play positive role for the province's reform and innovation. Innovation is the first force of development. Only through continuous innovation, enterprises can improve or remain competitive.

Third, people had better strengthen education and the reserves of talent. The airport is a comprehensive area involving a wide range of disciplines and fields. To achieve rapid development, the key is to have high-quality talent. Although the population of Henan is big, but the level of per capita education is low. Therefore, it is advisable to enhance the training of professionals. Relevant departments can simultaneously implement local training, on-the-job training and foreign introduction strategy, so we can provide professional talent and management skills to industrial development of Airport Zone.

\section{CONCLUSIONS}

The "B\&R" initiative is an opportunity for Zhengzhou Airport Zone, which can lead economic of Henan to develop rapidly and build an international airpot logistics center. It would be best for Zhengzhou Airport Zone to seize the opportunity, face challenges bravely, play their own advantages, fight for a national logistics distribution center and a comprehensive, modernized and international logistics hub city, being a leader of national economic development.

\section{REFERENCES}

[1] Guoyou Song, 2015. The Strategic Vision of the "Belt and Road" and a New Development of China's Economic Diplomacy, Peace. (04), 15-23.

[2] Jiayuan Wang, 2015. New Opportunities in Henan Province under the Regional Development Strategy of “B\&R”, Manager' journal. (07),181.

[3] Jingli Jiu, 2014. The Problem and Countermeasure of Aviation Logistics Development in Zhengzhou Airport Comprehensive Economic Experimental Zone, Modern Industrial Economy and Informatization. 4(23), 39-41.

[4] Xiaoyan Zhu, 2017. Analysis of the Status Quo and Opportunities of Aviation Logistics Industry in Zhengzhou Aviation Port Area under the Strategic Background of "B\&R", Science and Technology Economy. (26), 268-269.

[5] Xinhong Pei, 2016. The opportunities and challenges that "B\&R" strategy has brought to Zhengzhou, Rural Economy and Science-Technology. 27(01),142-143. 
[6] Xinshun Tong, Xiaokang Qin, 2014. Research on the Countermeasures of Building the Logistics Corridor Hub of the Silk Road Economic Belt in Zhengzhou, Logistics Engineering and Management. 36(10), 15-16+20.
[7] Yang Zhou, 2014. Development Countermeasures of Aviation Logistics in Zhengzhou Airport Economic Experimental Zone, Logistics Engineering and Management. (5), 23-25. 